\title{
Chillers of air-conditioning systems: An overview
}

\author{
Michael Kwok Hi Leung, Chi Yan Tso, Wei Wu, Zhanying Zheng and Jingyu Cao \\ School of Energy and Environment, City University of Hong Kong, Hong Kong, People's Republic of China
}

\begin{abstract}
In tropical and subtropical regions, air-conditioning commonly consumes the most energy in buildings. The chillers used in existing air-conditioning systems are largely based on thermodynamic vapour compression cycle because the cycle is highly effective, efficient and practical. Moreover, the system installation and operation are convenient when grid electricity is available. Popular vapour compression chiller types include air-cooled, water-cooled, seawater-cooled and oil-free chillers. In addition, thermal-driven absorption and adsorption chillers have become available in the market. Viable sources of thermal energy input include fuel combustion, renewable solar energy, waste heat, and so on. This paper provides an overview of different types of chillers and system configurations in terms of mechanisms, characteristics, energy efficiency, environmental performance and costs. The technical information and comparisons should help engineers select the chiller type in air-conditioning system design for achieving high sustainability.
\end{abstract}

KEYWORDS Vapour compression cycle; oil free chiller; absorption cooling; adsorption cooling; energy efficiency; carbon footprint; cost analysis

CONTACT Michael Kowk Hi Leung mkh.leung@cityu.edu.hk

Received 21 November 2019

\section{Introduction}

Air-conditioning is the major form of energy consumption in Hong Kong buildings (Figure 1). Similar energy consumption distribution is found in other cities in the tropical and subtropical regions. Due to global urbanisation and economic growth, the energy demand for air-conditioning will continue to increase worldwide (Figure 2). Therefore, energy-efficient air-conditioning has a high energy saving potential as well as carbon emission reduction potential among other energy consumers in the building sector.

In a central heating, ventilation and air-conditioning (HVAC) system, the chillers are considered as key units as they produce the cooling effect required and account for most of the electricity consumption. There are different types of chillers available in the market, including conventional vapour compression chiller, oil-free chiller, absorption chiller and adsorption chiller. Each type has its own unique features, advantages and limitations. Depending on the specific site conditions and requirements, one chiller type may fit better than the others. In this paper, the cooling mechanisms of each chiller type and their characteristics, energy efficiency, environmental impacts and costs will be discussed. The technical information can facilitate selection of chillers in HVAC system design, and thus, yield significant energy saving, carbon emission reduction as well as cost saving.

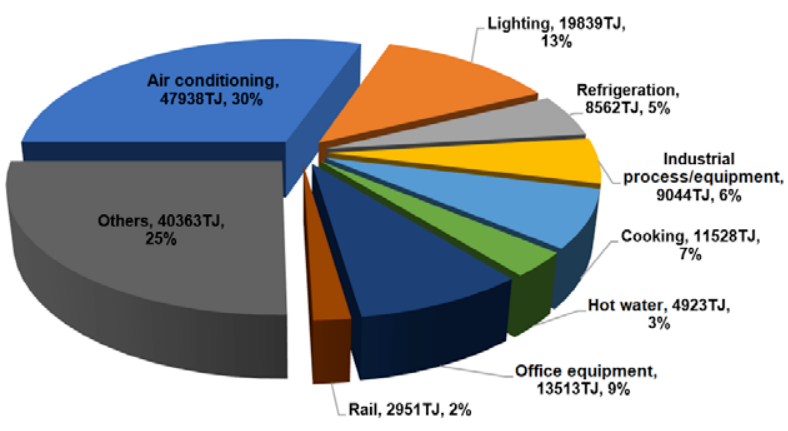

Figure 1. Annual electricity consumption distribution in Hong Kong (HKSAR Government, 2018: pp.63-68).

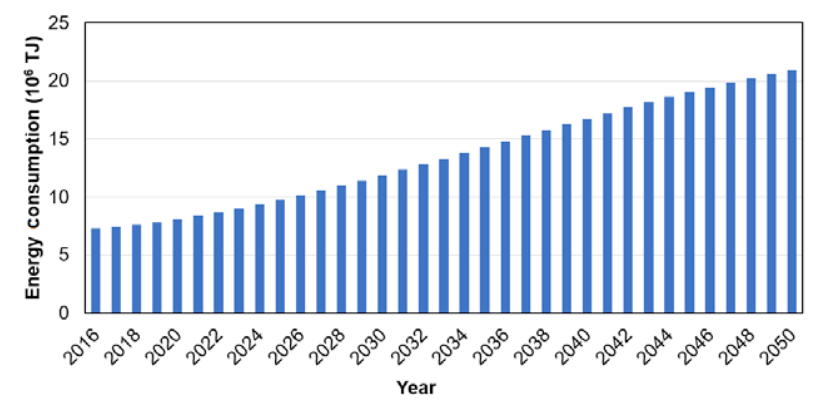

Figure 2. Energy demand for air-conditioning worldwide (Paris: International Energy Agency, 2018: p.1). 


\section{Vapour compression chiller}

\subsection{Vapour compression cycle}

Vapour compression (VC) cycle, as illustrated in Figure 3, is the most commonly used refrigeration cycle in air-conditioning systems from small-scale domestic units to large-scale central chiller plants (ASHRAE HandbookFundamentals, 2017). The four main components of the $\mathrm{VC}$ cycle are compressor, condenser, expansion device and evaporator. As the refrigerant passes through the expansion device, it undergoes expansion from liquid to saturated liquid and vapour. In this process, the temperature of the refrigerant drops to a low level $\left(1^{\circ} \mathrm{C}-5^{\circ} \mathrm{C}\right)$. Then, the cooling effect occurs at the evaporator as the cold refrigerant absorbs heat from the chilled water return $\left(11^{\circ} \mathrm{C}-15^{\circ} \mathrm{C}\right)$ to produce low-temperature chilled water supply $\left(6^{\circ} \mathrm{C}-10^{\circ} \mathrm{C}\right)$. The energy efficiency of the cycle can be measured in terms of the coefficient of performance (COP), defined as the ratio of the cooling effect to the compressor work. It is noted that the air-conditioning system performance can be measured in terms of system COP, defined as the ratio of the cooling effect to the energy consumed by the chiller and other components, e.g. pumps and fans (Aprea and Greco, 2002).

\subsection{Refrigerant}

There are many different refrigerants that can work effectively as the working fluid in VC cycle. Choosing the right refrigerant yields high COP as well as low carbon footprint. In the past, chlorodifluoromethane, also known as R22, was widely used from domestic to large-scale applications due to its excellent thermodynamic properties to achieve high COP. However, as it has a considerable level of ozone depletion potential (ODP), R22 has been phased out under the Montreal Protocol on Substances that Deplete the Ozone Layer. Various hydrofluorocarbons (HFCs) became available in the market as substitutes to R22, e.g. R410A and R134a. Recently, the use of HFCs has also been increasingly restricted since they are greenhouse gases (GHGs) with high global warming potential (GWP). In case of leakage, the fugitive emission of GHG will adversely contribute to climate change. Refrigerants for the next generation have been proposed although each substance has its limitations as summarised in Table 1.
R32 has been adopted by some manufacturers in the airconditioning industry. Refrigerant blends have also been suggested for additional advantages.

(a)

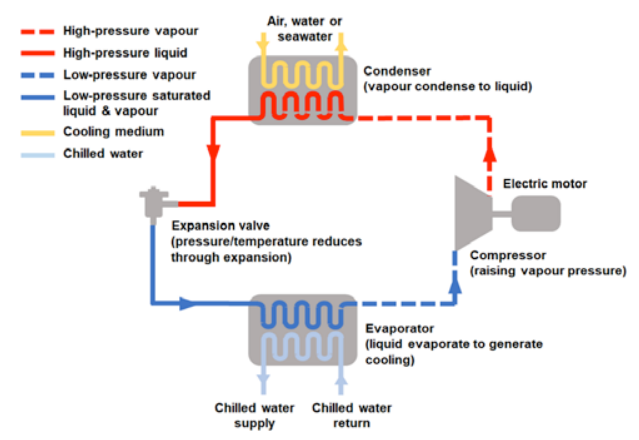

(b)

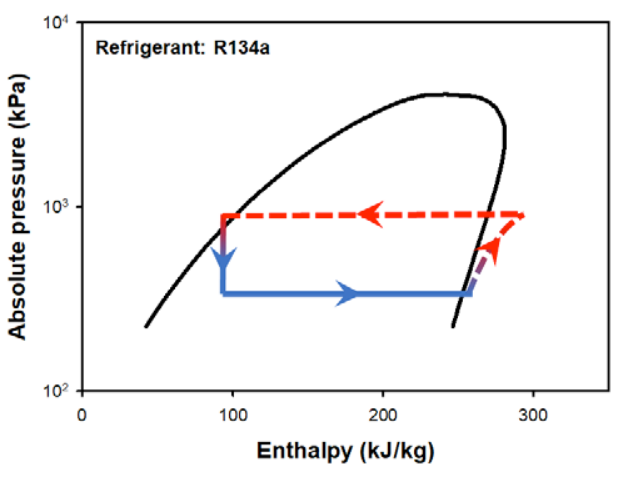

(c)

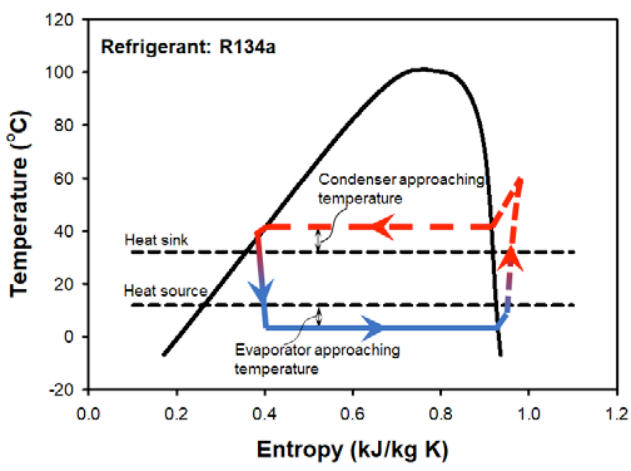

Figure 3. Vapour compression chiller: (a) schematics; (b) pressure-enthalpy $(P-h)$ diagram; and $(c)$ temperatureentropy $(T-s)$ diagram of typical operation using refrigerant R134a.

Table 1. Potential environmental-friendly refrigerants for future air-conditioning industry.

\begin{tabular}{|l|l|l|l|}
\hline \multicolumn{1}{|c|}{ Potential refrigerant } & \multicolumn{1}{c|}{ Refrigerant type } & \multicolumn{1}{c|}{ Ddvantages } & \multicolumn{1}{c|}{ Disadvantages } \\
\hline R290, R1270 & Hydrocarbon (HC) & Very low GWP; zero ODP & Flammable \\
\hline R32 & Hydrofluorocarbon (HFC) & $\begin{array}{l}\text { Low GWP; zero ODP; minimum changes required } \\
\text { to existing equipment }\end{array}$ & Mildly flammable \\
\hline R1234ze(E), R1234yf & Hydrofluoroolefin (HFO) & Very low GWP; zero ODP & Flammable \\
\hline R717 (Ammonia) & Natural refrigerant & Zero GWP; zero ODP & Mildly flammable; toxic \\
\hline R744 $\left(\mathrm{CO}_{2}\right)$ & Natural refrigerant & Negligible GWP; zero ODP; non-flammable & High working pressure \\
\hline
\end{tabular}




\subsection{Compressor}

Compressor is the most important component in a chiller as it is responsible for driving the flow of refrigerant in the VC cycle (ASHRAE Handbook-Fundamentals, 2017). It is similar to the heart in our blood circulation system. The compressor accounts for most of the electricity consumed by the entire air-conditioning system. There are different types of compressors available in the industry, including scroll, reciprocating, screw and centrifugal compressors. Their characteristics are summarised in Table 2. Based on the initial costs and operating costs, each compressor type has a favourable range of cooling capacity.

\subsection{Condenser}

The COP of a chiller highly depends on the heat rejection effectiveness of the condenser. An air-cooled condenser (Figure 4(a)) is a heat exchanger that uses ambient air to cool the hot superheated vapour refrigerant until it fully turns to liquid. In a water-cooled condenser (Figure 4(b)), the condenser is directly cooled by water and a cooling tower is used to reject the heat from the condensing water by latent heat of vaporisation. It is more convenient to install and operate an air-cooled condenser than a water-cooled condenser because the cooling tower occupies more space and requires condensing water treatment. However, the water-cooled condenser is a more effective heat exchanger than the air-cooled condenser as water has a much higher specific heat capacity than air. A seawater-cooled condenser (Figure 4(c)) uses seawater to cool the refrigerant and then the seawater is discharged back to the sea. Seawater-cooled condenser is more effective than water-cooled condenser because the seawater intake is colder than the counterpart. However, fouling problem occurs in seawater-cooled condenser. Automatic condenser tube cleaning devices can solve the fouling problem effectively (ASHRAE HandbookFundamentals, 2017). The typical COP values of chillers using different heat rejecting media are shown in Figure 5 (Bitzer Software, 2019). Figure 6 further presents the COP of chillers using different compressors and condensers based on specifications provided by major manufacturers. The standard test conditions of water-cooled chillers are as follows: the entering and leaving water temperatures of the evaporator are $12^{\circ} \mathrm{C}$ and $7{ }^{\circ} \mathrm{C}$, respectively; and the entering and leaving water temperatures of the cooling tower are $30^{\circ} \mathrm{C}$ and $35^{\circ} \mathrm{C}$, respectively. (a)

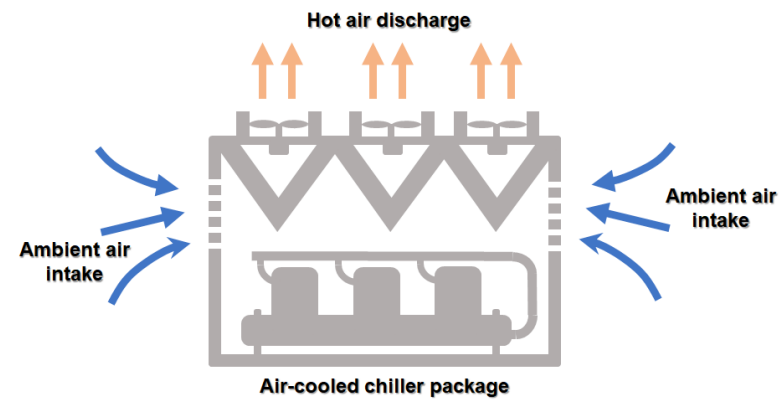

(b)

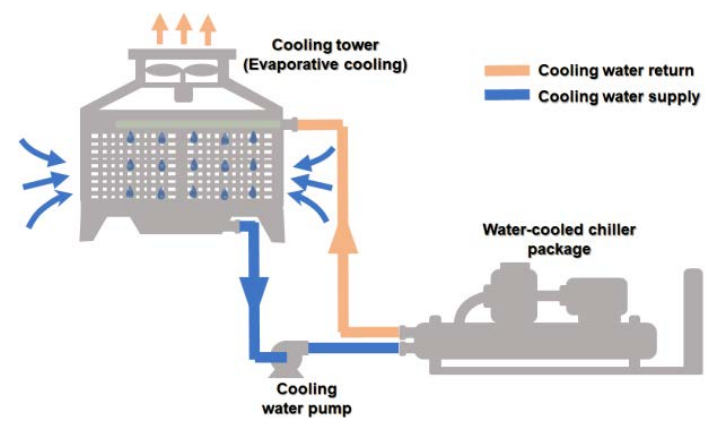

(c)

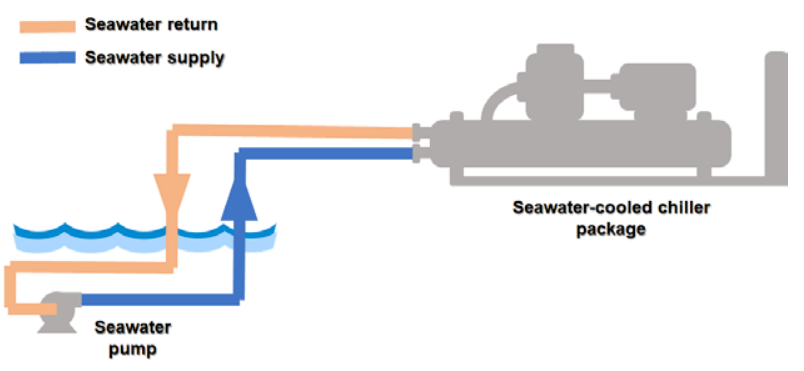

Figure 4. Chillers using different condenser types: (a) aircooled condenser; (b) water-cooled condenser; and (c) seawater-cooled condenser.

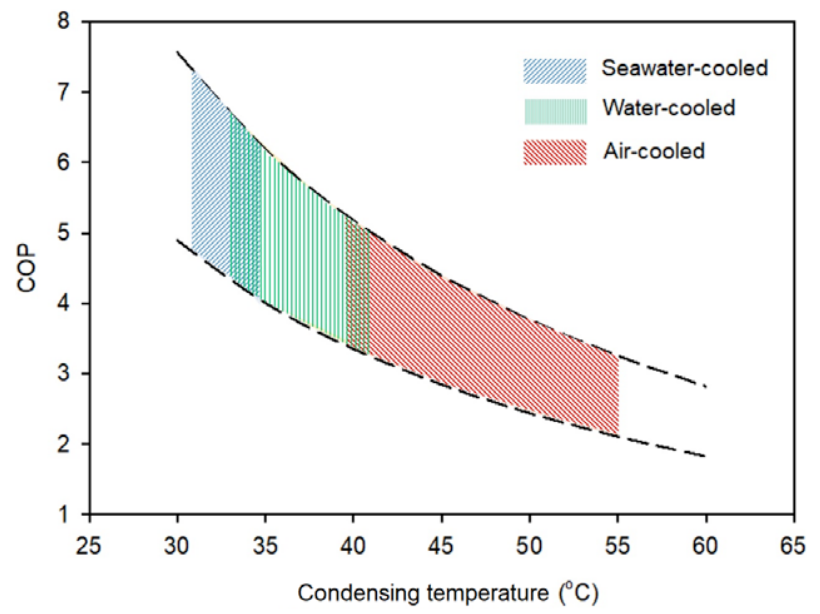

Figure 5. Typical COP of air-cooled, water-cooled and seawater-cooled chillers. 


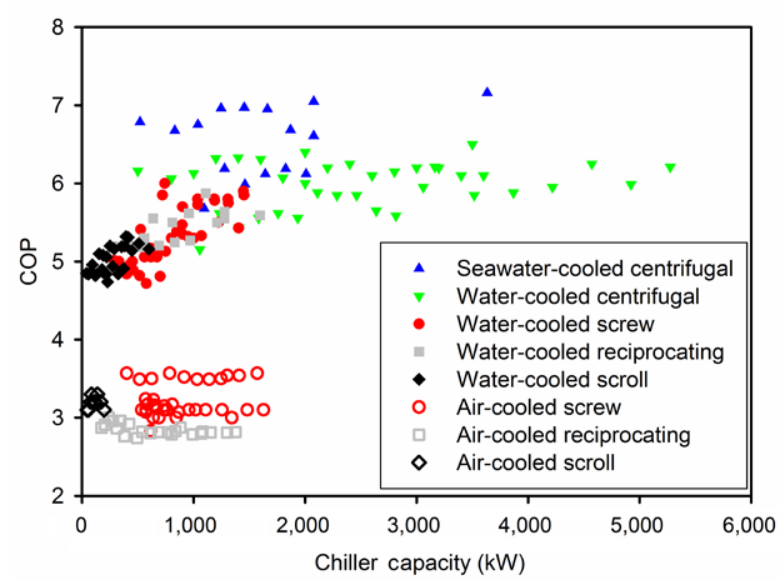

Figure 6. COP of chillers using different compressors and condensers.

\subsection{Component enhancement}

Many attempts in component enhancement for conventional vapour compression chillers have achieved encouraging results. Recently, modification on the heat exchanger structure has received much attention. Cao et al. (2020) utilised passive two-phase heat transfer devices to reduce the need for variable frequency operation. Singhal et al. (2019) designed a porous wick cloth for the condenser to improve its heat transfer capability, resulting in about
$32.4 \%$ enhancement in COP with a maximum ambient temperature of $35^{\circ} \mathrm{C}$. Abubaker et al. (2020) proposed the use of innovative fin-tube heat exchanger as the condenser of a cooling system and the COP increased by $4.7 \%$.

\section{Oil-free chiller}

\subsection{Magnetic bearing}

Oil-free chillers are similar to conventional VC chillers. The main difference between oil-free chillers and VC chillers is in the compressors. In an oil-free chiller, the compressor is equipped with magnetic bearings. As shown in Figure 7, the magnetic bearings are non-contacting devices, and thus, they do not require lubricating oil. The magnetic bearing compressor is more energy efficient because the VC chiller using oil-lubricated compressor consumes more energy to drive the flow of refrigerant as the lubricating oil is miscible with the refrigerant (Yu et al., 2015). Moreover, the deposition of lubricating oil onto the heat exchanger surfaces declines the overall heat transfer coefficient due to its low thermal conductivity (Kedzierski, 2001). Furthermore, the presence of the lubricating oil reduces the bubble size of departure in the phase change process, resulting in poor heat transfer.

In oil-free chillers, there are two major types of magnetic bearing systems, namely, active magnetic bearing

Table 2. Characteristics of chillers using different compressor types (HKSAR government, 2015: pp.5-10; Johnson Controls, 2018: pp.8-12; GEA North America, 2020: pp.11-19; Carrier Corporation, 2019: pp.2-5; Aprea et al., 2003: pp.653-669; Aprea et al., 2009: pp.1995-1997).

\begin{tabular}{|c|c|c|c|c|c|c|}
\hline Compressor type & Operating principle & Cooling capacity & $\begin{array}{c}\text { Full-load } \\
\text { performance }\end{array}$ & Part-load operation & $\begin{array}{c}\text { Equipment cost } \\
\text { per } k W \text { cooling }(\mathrm{HKD})\end{array}$ & $\begin{array}{c}\text { Maintenance } \\
\text { cost }\end{array}$ \\
\hline Scroll & $\begin{array}{l}\text { Compressing gas using } \\
\text { two inter-fitting; spiral- } \\
\text { shaped scroll members }\end{array}$ & $\begin{array}{l}50 \mathrm{~kW}- \\
1,300 \mathrm{~kW}\end{array}$ & Good & $\begin{array}{l}\text { Mostly via speed variation or } \\
\text { with a multiple-compressor } \\
\text { arrangement }\end{array}$ & $900-2,000$ & Low \\
\hline Reci] & $\begin{array}{l}\text { Using pistons driven by } \\
\text { a crankshaft to deliver } \\
\text { gas at higher pressure }\end{array}$ & $\begin{array}{l}200 \mathrm{~kW}- \\
2,400 \mathrm{~kW}\end{array}$ & Good & $\begin{array}{l}\text { Staged capacity control via } \\
\text { cylinder unloaders; COP not } \\
\text { affected during part-load } \\
\text { operation }\end{array}$ & $600-1,300$ & High \\
\hline Screw & $\begin{array}{l}\text { Using helical rotors to } \\
\text { reduce the refrigerant } \\
\text { gas volume as they } \\
\text { rotate to achieve } \\
\text { compression }\end{array}$ & $\begin{array}{l}200 \mathrm{~kW}- \\
5,800 \mathrm{~kW}\end{array}$ & Excellent & $\begin{array}{l}\text { Poor COP via slide valve } \\
\text { capacity control; can be } \\
\text { improved via variable speed } \\
\text { capacity control }\end{array}$ & $600-1,400$ & Medium \\
\hline Centrifugal & $\begin{array}{l}\text { Refrigerant gas } \\
\text { compressed via rotating } \\
\text { impellers }\end{array}$ & $\begin{array}{c}500 \mathrm{~kW}- \\
21,000 \mathrm{~kW}\end{array}$ & Excellent & $\begin{array}{l}\text { Mostly via speed variation } \\
\text { and COP remains high }\end{array}$ & $\begin{array}{c}700-1,400 \\
(\leq 1,500 \mathrm{~kW}) \\
350-800 \\
(>1,500 \mathrm{~kW})\end{array}$ & Low \\
\hline
\end{tabular}


and passive magnetic bearing (Figure 7). The active magnetic bearing is formed by coils which generate a magnetic field by an alternating current. The properties of the active magnetic bearing include good controllability and damping effect, but poor reliability and availability because of the complicated control (Du et al., 2019; Guan et al., 2019; Sun et al., 2019).

Passive magnetic bearing using permanent magnets has a simpler structure (Jinji et al., 2011; Ohji et al., 2011). The advantages include high reliability and low energy consumption because a passive magnetic bearing system does not involve any electronic control. However, it is not favourable to high speed rotation due to the lack of damping. Without damping, the rotor is vulnerable to synchronous vibration excitation.

(a)

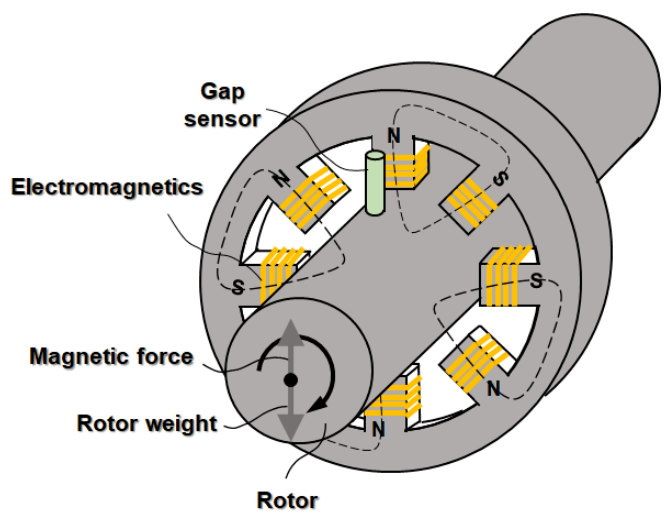

(b)

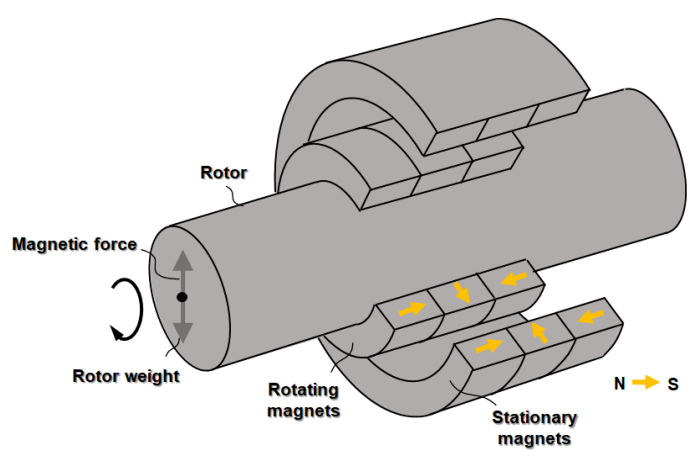

Figure 7. (a) Active and (b) passive magnetic bearing systems for oil-free chillers.

\subsection{Operation and performance}

Similar to VC chillers, the oil-free chillers can operate with variable speed so that it can significantly save $20 \%$ of the energy consumption (Aprea et al., 2006). Yu and Chan (2008) consistently found that the annual savings in energy consumption and water usage of the variable speed oil-free chiller were $19.7 \%$ and $15.9 \%$, respectively. However, the initial cost of the oil-free chillers is about twice of that of conventional VC chillers (Yu et al., 2015). Low economic benefit is the major barrier to commercialisation of oil-free chillers in the present market. The COP of oil-free chillers normally lies between 5 and 6 at the full load condition.

Integrated part load value (IPLV) is another parameter for evaluating the performance of a chiller operating in part load. IPLV is defined as the weighted average of COP at $25 \%, 50 \%, 75 \%$ and $100 \%$ of the full capacity and the weighting factors are $0.12,0.45,0.42$ and 0.01 , respectively. Yu et al. (2017) compared the IPLV between a constant speed centrifugal chiller and a variable speed oilfree chiller, and the values were 8.7 and 10.7, respectively. It means that variable speed oil-free chillers have a better performance than constant speed centrifugal chillers in different loading conditions. The average system COP increased from 6.2 to 10.3 in the chiller replacement. Yu et al. (2017) also conducted a retrofit project in which constant speed centrifugal chillers were replaced by variable speed oil-free chillers in a shopping arcade in Hong Kong. They found that an energy saving of $9.6 \%$ was achieved. The total capital cost of the chiller replacement was about 6 million HKD and the annual cost saving was approximately 1 million HKD, resulting in a payback period of around six years. It should be noted that the variable speed oil-free chillers normally have a ten-year life span.

It is also found that oil-free chillers require less maintenance services (Parker and Blanchard, 2012) and thus the downtime is low. In principle, the maintenance cost is also low. However, since presently there are few trained suppliers offering maintenance contracts of oil-free chillers, the maintenance cost may be high in the less competitive market. Replacement of conventional VC chillers by variable speed oil-free chillers is a profitable long-term investment.

\subsection{Feasibility}

The use of oil-free chillers in Hong Kong is effective because of the high demand for air-conditioning and the potential energy saving is high with a short payback period. Moreover, the electricity indirect GHG emissions, such as carbon dioxide and nitrous oxide, can be reduced. Therefore, the use of oil-free chillers is an environmentally friendly strategy. The oil-free chillers are relatively not susceptible to ambient temperature and humidity, so they are applicable to Hong Kong in which the climate is relatively hot and humid. Similar to VC chillers, the space requirement of oil-free chillers is low. Since space in Hong Kong is very limited, compact oil-free chillers are favourable. It is noted that active magnetic regenerative refrigeration, another advanced technology adopting magnetism to produce cooling effect, also has a high potential for achieving energy efficient air-conditioning (Aprea et al., 2012; Aprea et al., 2014). The choice of magnetic material is of crucial importance and the development of advanced magnetic materials has received much attention (Aprea et al., 2015; Pecharsky and Gschneidner, 2006). 


\section{Absorption chiller}

\subsection{Absorption cooling}

Absorption chiller is a thermal-driven chiller, in which the cooling effect is produced by heat utilisation as the main energy input (Sarbu and Sebarchievici, 2013). The basic single-effect absorption cycle is illustrated in Figure 8. There are similarities between the absorption cooling cycle and the VC cycle. The main difference is that instead of vapour compression driven by electric compressor in $\mathrm{VC}$, the refrigerant vapour in the absorption cycle is raised to high pressure by the following sequential process: (1) absorption into liquid form, (2) pumping of liquid to high pressure and (3) heating desorption to release high-pressure refrigerant vapour. In the absorption cycle, the main energy input is the thermal energy consumed in the heating process. Therefore, the COP can be defined as the ratio of the cooling effect to the heat input. Single-effect absorption chillers are designed for medium-temperature heat sources $\left(80^{\circ} \mathrm{C}-120^{\circ} \mathrm{C}\right)$. The typical COP is $0.5-0.7$.

Multi-effect absorption chillers can enhance the cycle performance when high-temperature heat source is available, with the double-effect and triple-effect cycles being the majority (Gebreslassie et al., 2010). Double-effect absorption chillers are driven by heat at high temperature $\left(120^{\circ} \mathrm{C}-170^{\circ} \mathrm{C}\right)$ and yield high COP $(1.0-1.2)$. Tripleeffect absorption chillers are driven by heat at even higher temperature $\left(200^{\circ} \mathrm{C}-230^{\circ} \mathrm{C}\right)$ and yield even higher COP $(1.4-1.7)$.
Comparing with a VC chiller of the same cooling capacity, an absorption chiller requires a considerably larger condenser to accommodate its higher heat rejection. Thus, the space requirement of the entire absorption cooling system is much higher.

\subsection{Working fluids}

Working fluids, consisting of refrigerant and absorbent, play an important role in the performance of absorption chillers. $\mathrm{H}_{2} \mathrm{O}$-based working fluids are the most widely used for absorption chillers, with $\mathrm{H}_{2} \mathrm{O}$ (refrigerant)$\mathrm{LiBr}$ (absorbent) being the majority (Herold et al., 2016). $\mathrm{H}_{2} \mathrm{O}$-based working fluids feature high efficiency, low cost and safe operation (Horuz, 1998). However, they also have some limitations: (1) high freezing point of $\mathrm{H}_{2} \mathrm{O}$ does not facilitate subfreezing refrigeration (Karamangil et al., 2010; Muthu et al., 2008); (2) $\mathrm{H}_{2} \mathrm{O}-\mathrm{LiBr}$ solution is subject to crystallisation affecting the reliability of the chiller (Izquierdo et al., 2004; Wang et al., 2011); and (3) high vacuum condition is required for efficient operation of the $\mathrm{H}_{2} \mathrm{O}-\mathrm{LiBr}$ chiller. Various alternatives have been explored to reduce crystallisation of $\mathrm{H}_{2} \mathrm{O}$-salt pairs, e.g. adding salts (Jian et al., 2010; Kim et al., 1999) and using $\mathrm{H}_{2} \mathrm{O}$ ionic liquid (IL) mixtures (Dong et al., 2013; Yokozeki and Shiflett, 2010).

$\mathrm{NH}_{3}$-based working fluids are also popular for absorption chillers, with $\mathrm{NH}_{3}$ (refrigerant) $-\mathrm{H}_{2} \mathrm{O}$ (absorbent) being the majority (Wu et al., 2014a). Compared with $\mathrm{H}_{2} \mathrm{O}$ $\mathrm{LiBr}, \mathrm{NH}_{3}-\mathrm{H}_{2} \mathrm{O}$ shows slightly lower $\mathrm{COP}$ and requires

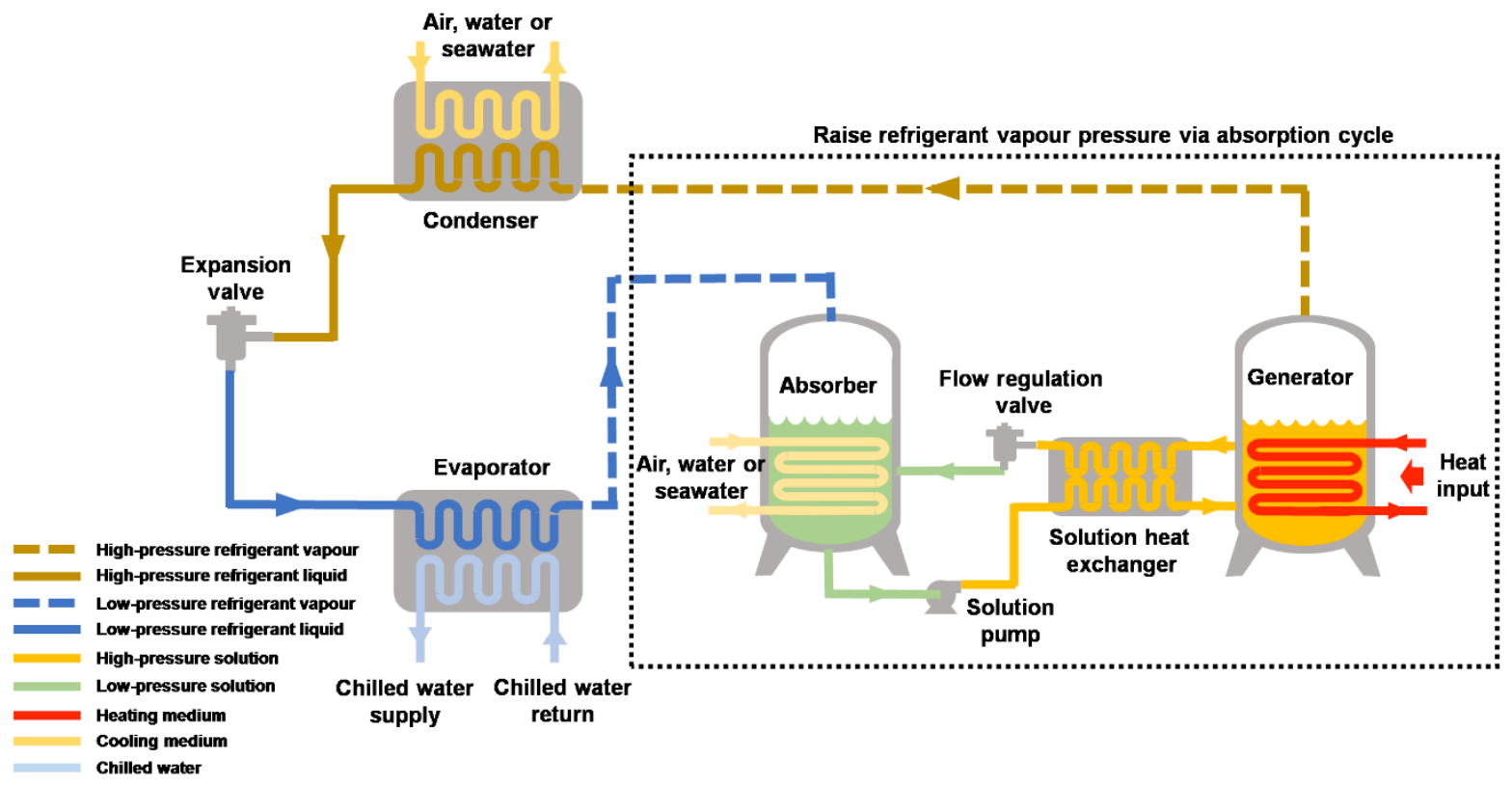

Figure 8. Single-effect absorption chiller. 
a rectifier for refrigerant purification due to the small difference in boiling points of $\mathrm{NH}_{3}$ and $\mathrm{H}_{2} \mathrm{O}$ (Berlitz et al., 1998). However, there are advantages of the $\mathrm{NH}_{3}-\mathrm{H}_{2} \mathrm{O}$ chillers (Wu et al., 2013; Wu et al., 2014c): (1) subfreezing refrigeration is possible due to low freezing point of $\mathrm{NH}_{3}$; (2) there is no concern of crystallisation; and (3) operating pressures are higher than the atmospheric pressure to avoid air infiltration. Various novel $\mathrm{NH}_{3}$-based working fluids have been studied to remove the rectifier and reduce the complexity (Wu et al., 2012; Wu et al., 2014a). These working fluids include $\mathrm{NH}_{3}-\mathrm{NaSCN}, \mathrm{NH}_{3}-\mathrm{LiNO}_{3}$ (Cai et al., 2016; Cerezo et al., 2011) and $\mathrm{NH}_{3}$-IL mixtures (Wu et al., 2018; Yokozeki and Shiflett, 2007).

The biggest concern for $\mathrm{NH}_{3}$-based absorption chillers is that the working fluid, i.e. $\mathrm{NH}_{3}$, is toxic and flammable. Additional safety measures are therefore required in the design and operation of the chiller plants. For $\mathrm{H}_{2} \mathrm{O}-\mathrm{LiBr}$ chillers, the corrosion issue needs to be noted as it may cause the failure of system pipelines.

\subsection{Heat sources}

Fossil fuels are the most widely used energy source due to the wide availability and high stability. Among various fossil fuels, natural gas and oil can be used for direct-fired absorption chillers, of which fuels are combusted directly in the burners (Wang and Li, 2007; Wu et al., 2014b). Direct-fired absorption chillers usually adopt the double-effect, triple-effect or generator-absorberheat-exchange (GAX) cycles due to the high combustion temperatures. Direct-fired absorption chillers can also supply hot water as a by-product (Yoon et al., 2003). As for coal, it is used by boilers to produce hot water or steam, which then drives the absorption chillers.

Renewable energy sources, including solar energy (Fan et al., 2007; Zhai et al., 2011), geothermal energy (Keçeciler et al., 2000) and biomass energy (Anbazhaghan et al., 2005), have also been used for absorption chillers. Normally, due to low temperature level, conventional solar collectors and geothermal wells can only power singlestage or multi-stage absorption chillers to obtain a low COP. With high-temperature solar thermal collectors (FernándezGarcía et al., 2010; Tian et al. 2018), solar energy can also be used for multi-effect or GAX cycles. As for biomass energy, similar to natural gas, it is suitable for multi-effect or GAX cycles due to the high combustion temperature.

Waste heat is available in the flue gas of boilers and the processes of industries, with temperatures typically in the range of $80^{\circ} \mathrm{C}-200^{\circ} \mathrm{C}$. Depending on the actual temperature levels, the waste heat can be recovered to drive single-stage, multi-stage, multi-effect or GAX cycles (Cao et al., 2015; Kang et al., 1999; Manzela et al., 2010). As renewable energy and waste heat are often intermittent, energy storage technologies are essential (Sharma et al., 2009; N'Tsoukpoe et al., 2009; Zhang et al., 1999); otherwise, auxiliary fossil fuels are required.

For direct-fired absorption chillers, emission control measures should be implemented to ensure the exhaust gas of the combustion of fuel does not cause air pollution. Additional space is also required for exhaust discharge components, such as chimneys.

\subsection{Chiller performance}

The operating conditions and performance of different absorption chillers are summarised in Table 3 . The typical COP of absorption chillers is much lower than that of VC chillers. Therefore, the use of absorption chillers is justified only if the heat source is at low or zero cost, such as waste heat or renewable source.

Compared with VC chillers, absorption chillers have a longer start-up time and slow response to load variation, which may cause a reduction of its performance for applications with rapidly changing load profile and frequent system start/stop. Moreover, the energy consumption by auxiliary equipment is higher for an absorption chiller since the system is composed of large cooling tower fans and additional fans and motors in the combustion part.

Table 3. Performance of absorption chillers (Alobaid et al., 2017: p.735; Deng et al., 2011: p.177; Ghafoor and Munir, 2015: pp.779-770; Kim and Intante Ferreira, 2008: pp.9-11).

\begin{tabular}{|c|c|c|c|c|c|c|}
\hline $\begin{array}{c}\text { Working } \\
\text { fluids }\end{array}$ & $\begin{array}{c}\text { Cycle } \\
\text { configuration }\end{array}$ & $\begin{array}{c}\text { Chilled } \\
\text { water supply } \\
\text { temperature }\left({ }^{\circ} \mathbf{C}\right)\end{array}$ & $\begin{array}{c}\text { Heat source } \\
\text { temperature }\left({ }^{\circ} \mathbf{C}\right)\end{array}$ & $\begin{array}{c}\text { Capacity } \\
(\mathbf{k W})\end{array}$ & COP & Cost (HKD/kW) \\
\hline $\mathrm{H}_{2} \mathrm{O}-\mathrm{LiBr}$ & Single-effect & $5-10$ & $80-120$ & $35-7000$ & $0.5-0.7$ & $11,900-15,800$ \\
\hline $\mathrm{H}_{2} \mathrm{O}-\mathrm{LiBr}$ & Double-effect & $5-10$ & $120-170$ & $20-11630$ & $1.0-1.2$ & - \\
\hline $\mathrm{H}_{2} \mathrm{O}-\mathrm{LiBr}$ & Triple-effect & $5-10$ & $200-230$ & $530-1400$ & $1.4-1.7$ & - \\
\hline $\mathrm{NH}_{3}-\mathrm{H}_{2} \mathrm{O}$ & Single-effect & $5-10$ & $80-120$ & $10-30$ & $0.5-0.6$ & $19,800-23,700$ \\
\hline $\mathrm{NH}_{3}-\mathrm{H}_{2} \mathrm{O}$ & Double-effect & $5-10$ & $160-200$ & $10-90$ & $0.7-0.9$ & - \\
\hline $\mathrm{NH}_{3}-\mathrm{H}_{2} \mathrm{O}$ & Triple-effect & $5-10$ & $170-200$ & $<110$ & $0.8-1.2$ & - \\
\hline $\mathrm{NH}_{3}-\mathrm{H}_{2} \mathrm{O}$ & Single-effect & $-60-0$ & $100-200$ & $10-6500$ & $0.25-0.6$ & - \\
\hline
\end{tabular}




\section{Adsorption chiller}

\subsection{Adsorption cooling}

Adsorption chiller, as illustrated in Figure 9, is also based on thermal-driven refrigeration mechanisms. Absorption and adsorption chillers share the similar working principle that both systems can be powered by thermal sources. The major difference is in the sorbent. Solid adsorbent (e.g. zeolite) is used in adsorption chillers and the refrigerant is adsorbed on the surface and internal voids of the adsorbent by physical phenomenon. Unlike absorption cooling, adsorption cooling does not utilise any toxic or corrosive sorbents. In other words, the refrigerantadsorbent working pairs are usually chemically inert and have little environmental impact (Chua and Chou, 2003). Besides, the adsorption chillers can be powered by a larger range of heat source temperature (Wang and Oliveira, 2006). The COP is usually very low, i.e. $<1$. However, the energy efficient ratio (EER), defined as a ratio of cooling effect to the electrical power consumed by pumps and fans, is relatively high, i.e. $>5$.

(a)

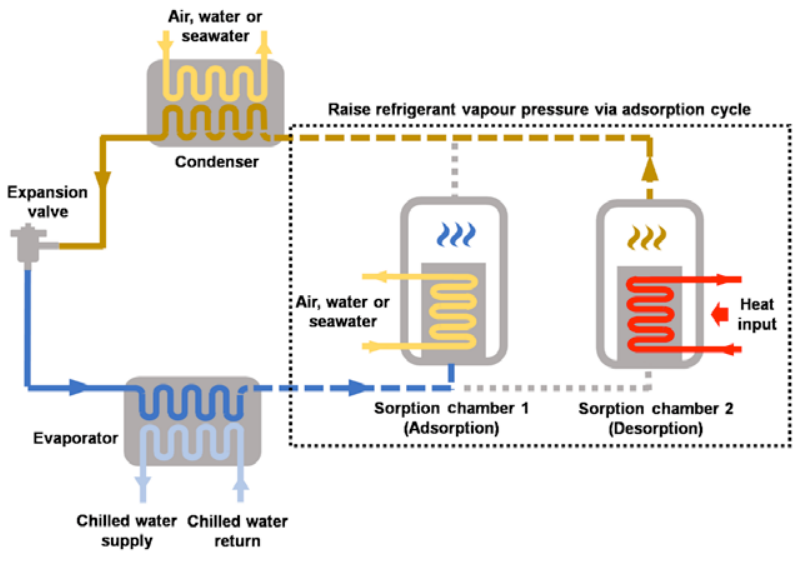

(b)

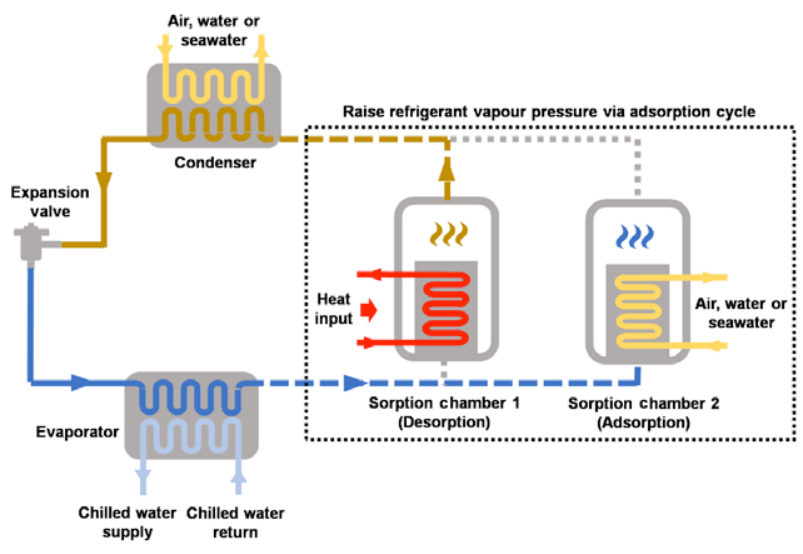

Figure 9. Adsorption chiller with sorption chamber 1 for (a) adsorption and (b) desorption.

\subsection{Ongoing development}

Adsorption chillers have not been widely commercialised at the current stage due to the following drawbacks: (1) long adsorption/desorption time, (2) low COP and (3) large size, leading to an increased energy consumption and cost. These problems can be overcome by enhancing the heat and mass transfer performance in the adsorber, evaporator and condenser, by improving the adsorption/desorption properties of the refrigerant-adsorbent working pairs and by better thermal management during the adsorptiondesorption cycle. Most recent research efforts on adsorption chillers are related to (1) high adsorption capacity/rate composite adsorbent (Allouhi et al., 2015; Gong et al., 2011; Tso and Chao, 2012; Ugale and Pitale, 2015; Xu et al., 2016), (2) design optimisation of adsorber (Rezk and Al-Dadah, 2012; Zhu et al., 2017), (3) modelling for predicting adsorption chiller behavior in different working/ operating conditions (Hassan et al., 2011; Nasruddin et al., 2015; Sharafian et al., 2015; Zhu et al., 2018a), (4) enhanced heat and mass transfer performance in evaporator and condenser (Thimmaiah et al., 2016; Xia et al., 2008; Zhu et al., 2018b) and (5) integration with clean energy and waste heat (Alam et al., 2013; Fadar, 2015; Koronaki et al., 2016; Tso et al., 2014; Zhu et al., 2018b). Up to the current stage, different types of adsorption chillers are built mostly based on the double-bed type (Alahmer et al., 2019; Alam et al., 2003; Chan et al., 2018; Chua et al., 2004; Habib et al., 2013; Hassan et al., 2011; Rezk and Al-Dadah, 2012; Rouf et al., 2013; Voyiatzis et al., 2008; Wang et al., 2004; Xia et al., 2008).

It is noted that the solar-powered adsorption chillers are effective as the daily cooling demand matches well with the availability of solar radiation (Oluleye and Boukhanouf, 2019). Both experimental study and modelling simulation have proven that a solar-powered adsorption chiller is more effective as well as economical in comparison with other adsorption chillers using clean energy (Li et al., 2019; Qadir et al., 2020).

\subsection{Practicality}

Practical applications of adsorption chillers in Hong Kong are limited at the current stage mainly due to its large size, which is around two to three times larger than conventional VC chillers. The mechanical floors of commercial buildings often cannot fulfil the space requirement for adsorption chillers. However, adsorption chillers can be considered for premises where large space is available, such as industrial buildings, remote areas, etc. Other factors favourable to adsorption chillers include unavailability of grid electricity and availability of renewable thermal energy and waste heat. 


\section{Practical applications and case studies}

In this section, the operational parameters, energy consumption, GHG emissions and costs of 1,000-RT VC chiller, oil-free chiller and double-effect absorption chiller are presented for direct comparisons (Ahmad et al., 2020; Simbolon and Hikmat, 2020). The analyses are based on actual chiller applications and system operations in Hong Kong. The results are summarised in Table 4. Taking the $\mathrm{VC}$ chiller as the base case, it is found that the oil-free chiller is able to achieve a payback in six years with a net present value of around 508,000 HKD. For an absorption chiller using town gas as the heat source, both capital and operational costs are significantly higher, indicating that it is not financially viable in Hong Kong at this stage. The absorption chiller also yields higher GHG emission. However, it may become sensible when a renewable or waste heat source is available, which will largely reduce its operating cost as well as GHG emission.

\section{Conclusions}

Different types of chillers in terms of cooling mechanisms, operational conditions, energy efficiency, environmental impacts, costs, etc. were discussed. The comparisons show that oil-free chillers have higher COP and possess other advantages for implementation in urban city. The high energy efficiency implies significant reduction in indirect $\mathrm{GHG}$ emissions. Conventional VC chillers are still highly competitive due to the low installation cost. Both thermal-driven absorption and adsorption chillers are more environmentally friendly when renewable or waste heat sources are used as the primary energy inputs. Absorption chillers are readily available as commercial products while adsorption chillers are under active research and development.

One apparent challenge the chiller industry faces is to identify the next generation refrigerant with a minimal GWP, non-flammability and excellent thermodynamic properties. For high-capacity units, the existing products have a reasonably high performance; however, the performance for small-scale units tends to drop significantly due to multiple factors, such as the type of compressor, capability of the heat exchanger and system control. Continual efforts are needed to mitigate the above shortcomings. For thermal-driven chillers, it is crucial to overcome the disadvantages of thermal source compared with electricity, e.g. reliability, stability, storage and longdistance transmission.
Table 4. Comparison of VC chiller, oil-free chill and absorption chiller on energy and costs.

\begin{tabular}{|c|c|c|c|}
\hline Parameter & VC chiller & Oil-free chiller & $\begin{array}{c}\text { Absorption } \\
\text { chiller }\end{array}$ \\
\hline $\begin{array}{l}\text { Cooling capacity } \\
\text { (RT) }\end{array}$ & 1,000 & 1,000 & 1,000 \\
\hline Full load COP & 6 & 6.6 & 1.36 \\
\hline Input energy $(\mathrm{kW})$ & 586 & 535 & 2,586 \\
\hline $\begin{array}{l}\text { Daily operating } \\
\text { hour (hours) }\end{array}$ & 16 & 16 & 16 \\
\hline $\begin{array}{l}\text { Daily energy } \\
\text { consumption }(\mathrm{kWh})\end{array}$ & 9,379 & 8,557 & 41,376 \\
\hline $\begin{array}{l}\text { Daily GHG } \\
\text { emission }\left(\mathrm{kgCO}_{2}\right)\end{array}$ & 4,783 & 4,364 & 9,748 \\
\hline $\begin{array}{l}\text { Daily energy cost } \\
(\mathrm{HKD})\end{array}$ & $\begin{array}{c}11,254 \\
\text { (Electricity rate: } \\
1.2 / \mathrm{kWh}) \\
\end{array}$ & $\begin{array}{c}10,269 \\
\text { (Electricity rate: } \\
1.2 / \mathrm{kWh})\end{array}$ & $\begin{array}{c}\text { 42,204 } \\
\text { (Town gas rate: } \\
1.02 / \mathrm{kWh} \text { ) } \\
\end{array}$ \\
\hline $\begin{array}{l}\text { Condensing water } \\
\text { pump power }(\mathrm{kW})\end{array}$ & 38 & 38 & 55 \\
\hline $\begin{array}{l}\text { Cooling tower fan } \\
\text { power }(\mathrm{kW})\end{array}$ & 18.5 & 18.5 & 30 \\
\hline $\begin{array}{l}\text { Burner fan \& } \\
\text { accessories }(\mathrm{kW})\end{array}$ & N/A & N/A & 22 \\
\hline $\begin{array}{l}\text { Daily auxiliary } \\
\text { power consumption } \\
(\mathrm{kW})\end{array}$ & 904 & 904 & 1,712 \\
\hline $\begin{array}{l}\text { Daily auxiliary } \\
\text { power cost }(\mathrm{kW}) \\
(\mathrm{HKD})\end{array}$ & 1,085 & 1,085 & 2,054 \\
\hline $\begin{array}{l}\text { Daily auxiliary } \\
\text { GHG emission } \\
\left(\mathrm{kgCO}_{2}\right)\end{array}$ & 461 & 461 & 873 \\
\hline $\begin{array}{l}\text { Daily water } \\
\text { consumption }\left(\mathrm{m}^{3}\right)\end{array}$ & 212 & 212 & 307 \\
\hline $\begin{array}{l}\text { Daily water cost } \\
(\mathrm{HKD})\end{array}$ & 1,590 & 1,590 & 2,303 \\
\hline $\begin{array}{l}\text { Daily total auxiliary } \\
\text { cost (HKD) }\end{array}$ & 2,675 & 2,675 & 4,357 \\
\hline $\begin{array}{l}\text { Annual operating } \\
\text { days }\end{array}$ & 150 & 150 & 150 \\
\hline $\begin{array}{l}\text { Annual operating } \\
\text { cost (HKD) }\end{array}$ & $2,089,380$ & $1,941,512$ & $6,984,135$ \\
\hline $\begin{array}{l}\text { Annual GHG } \\
\text { emission }\left(\mathrm{kgCO}_{2}\right)\end{array}$ & 786,624 & 723,780 & $1,593,212$ \\
\hline $\begin{array}{l}\text { Equipment capital } \\
\text { cost }(\mathrm{HKD})\end{array}$ & $3,000,000$ & $4,000,000$ & $4,500,000$ \\
\hline $\begin{array}{l}\text { Annual } \\
\text { maintenance cost } \\
(\mathrm{HKD})\end{array}$ & 100,000 & 80,000 & 150,000 \\
\hline Payback (years) & Base case & 6.0 & N/A \\
\hline $\begin{array}{l}\begin{array}{l}\text { Equipment lifespan } \\
\text { (years) }\end{array} \\
\end{array}$ & 10 & 10 & 10 \\
\hline $\begin{array}{l}\text { Net present value } \\
(\mathrm{HKD}) \text { (assumed } \\
\text { interest rate of } 2 \% \text { ) }\end{array}$ & Base case & 507,888 & N/A \\
\hline
\end{tabular}




\section{Note on Contributors}

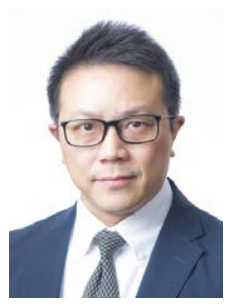

Prof Michael Kwok Hi Leung is a Professor in the School of Energy and Environment (SEE) at the City University of Hong Kong (City U). His research interests include advanced air-conditioning, solar photocatalysis and fuel cell. He developed integrated heat pump systems that fulfil cooling and heating demands in buildings at high efficiency. His research also emphasises the development of modified nanostructured materials to perform various functional photoelectrochemical activities. His research works are impactful and have received international recognition as he was listed as a Highly Cited Researcher by Clarivate Analytics in 2018. He is also listed as a Most Cited Scholar in Energy Science and Engineering by Shanghai Ranking Consultancy in collaboration with Elsevier.

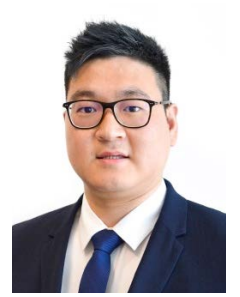

Dr Chi Yan Tso is currently an Assistant Professor of SEE at CityU. He received his bachelor's degree in Mechanical Engineering with first class honors, M.Phil. degree in Environmental Engineering and Ph.D. degree in Mechanical Engineering from The Hong Kong University of Science and Technology (HKUST) in 2010, 2012 and 2015, respectively. Before joining CityU, he served as Research Assistant Professor at the Department of Mechanical and Aerospace Engineering, HKUST and a Junior Fellow at the HKUST Jockey Club Institute for Advanced Study. His research interest covers thermofluid, energy conversion in a built environment, energy efficient building technology, particularly, in the fields of heat transfer, adsorption technology, thermal rectification, nanofluids, smart windows and passive radiative cooling using numerical simulations as well as advanced experimental techniques.

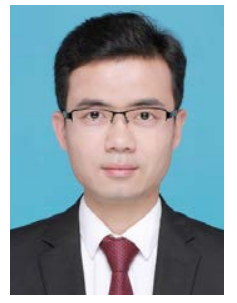

Dr Wei Wu obtained his Ph.D. degree from Tsinghua University, Beijing, People's Republic of China in 2016. He was a Visiting Scholar at University of Maryland, United States in 2013. Since 2016, he served as a Guest Researcher at the National Institute of Standards and Technology (NIST), United States. He joined CityU in 2018. His research is focused on sustainable building energy technologies, including novel absorption heating/cooling, renewable/waste energy utilisation, advanced heat pump, natural/low-GWP refrigerants, and net-zero energy buildings. He has obtained nine patents, published more than 50 Scientific Citation Index (SCI) journal papers, and published a book by Springer Nature. He received the IIR Willis H. Carrier Young Researcher, the NIST Distinguished Associate Award, and the Excellent Young Scholar Award of Energy and Built Environment.

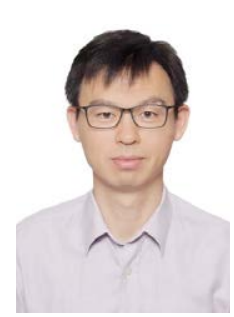

Dr Zhanying Zheng received his Ph.D. degree in the School of Chemical and Biomolecular Engineering at the University of Sydney, Australia in 2013. During his Ph.D. study, he developed a CFD methodology to study chaotic flow and heat transfer in tortuous microchannels, as well as a diagrammatic method for optimised heat exchanger design. After graduation, he joined a Sydney-based refrigeration and heating, ventilation and air-conditioning (HVAC) consultant company as a Thermal Engineer and was involved in more than 40 engineering projects. In February 2018, he moved to CityU as a Postdoctoral Scholar and had been working on a project for the conversion of low-grade waste heat into electricity. He is now an Assistant Professor at Harbin Institute of Technology, Shenzhen, People's Republic of China.

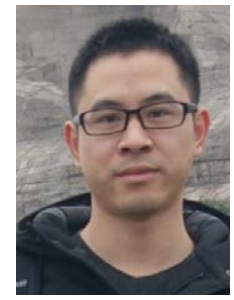

Dr Jingyu Cao is a Postdoctoral Researcher in SEE at CityU. His research interests include air-conditioning/ heat pump, efficient heat transfer, solar utilisation and energy saving technology. He conducted long-term research in integrated air-conditioning/ heat pump systems and advanced twophase loop thermosyphons/heat pipes. In the above fields, he has published more than 40 peer-reviewed papers in international journals or conferences and claimed 15 national patents. He has also received several awards, including the first-place winner of the China HVAC\&R Innovation Award and Excellent doctoral dissertation of University of Science and Technology of China (USTC).

\section{References}

[1] Abubaker AM, Najjar Y and Ahmad A (2020). A uniquely finned tube heat exchanger design of a condenser for heavy-duty air conditioning systems. International Journal of Air-Conditioning and Refrigeration, 28(01), pp. 2050004.

[2] Ahmad AD, Abubaker AM, Najjar YSH and Manaserh YMA (2020). Power boosting of a combined cycle power plant in Jordan: An integration of hybrid inlet cooling \& solar systems. Energy Conversion and Management, 214, pp. 112894.

[3] Alahmer A, Ajib S and Wang X (2019). Comprehensive strategies for performance improvement of adsorption air conditioning systems: A review. Renewable and Sustainable Energy Reviews, 99, pp. 138-158. 
[4] Alam KCA, Kang YT, Saha BB, Akisawa A and Kashiwagi T (2003). A novel approach to determine optimum switching frequency of a conventional adsorption chiller. Energy, 28(10), pp. 1021-1037.

[5] Alam KCA, Saha BB and Akisawa A (2013). Adsorption cooling driven by solar collector: A case study for Tokyo solar data. Applied Thermal Engineering, 50, pp. 1603-1609.

[6] Allouhi A, Kousksou T, Jamil A, El Rhafiki T, Mourad Y and Zeraouli Y (2015). Optimal working pairs for solar adsorption cooling applications. Energy, 79, pp. 235-247.

[7] Alobaid M, Hughes B, Calautit JK, O'Connor D and Heyes A (2017). A review of solar driven absorption cooling with photovoltaic thermal systems. Renewable and Sustainable Energy Reviews, 76, pp. 728-742.

[8] Anbazhaghan N, Saravanan R and Renganarayanan $\mathrm{S}$ (2005). Biomass based sorption cooling systems for cold storage applications. International Journal of Green Energy, 2(4), pp. 325-335.

[9] Aprea C and Greco A (2002). An exergetic analysis of R22 substitution. Applied Thermal Engineering, 22(13), pp. 1455-1469.

[10] Aprea C, Greco A and Maiorino A (2012). Modelling an active magnetic refrigeration system: A comparison with different models of incompressible flow through a packed bed. Applied Thermal Engineering, 36(1), pp. 296-306.

[11] Aprea C, Greco A and Maiorino A (2014). Magnetic refrigeration: A promising new technology for energy saving. International Journal of Ambient Energy, 37(3), pp. 1-52.

[12] Aprea C, Greco A, Maiorino A and Masselli C (2015). A comparison between rare earth and transition metals working as magnetic materials in an AMR refrigerator in the room temperature range. Applied Thermal Engineering, 91, pp. 767-777.

[13] Aprea C, Mastrullo R and Renno C (2006). Experimental analysis of the scroll compressor performances varying its speed. Applied Thermal Engineering, 26(10), pp. 983-992.

[14] Aprea C, Mastrullo R and Renno C (2009). Determination of the compressor optimal working conditions. Applied Thermal Engineering, 29(10), pp. 1991-1997.

[15] Aprea C, Rossi F, Greco A and Renno C (2003). Refrigeration plant exergetic analysis varying the compressor capacity. International Journal of Energy Research, 27(7), pp. 653-669.

[16] ASHRAE Handbook-Fundamentals (2017). GA: American Society of Heating Refrigeration and Air Conditioning Engineers. [online]. Available at: <https://www.ashrae.org/technical-resources/ ashrae-handbook $>$. [Accessed on 1 July 2019].
[17] Berlitz T, Plank H, Ziegler F and Kahn R (1998). An ammonia-water absorption refrigerator with a large temperature lift for combined heating and cooling. International Journal of Refrigeration, 21(3), pp. 219-229.

[18] Bitzer Software (2019). Sindelfingen: BitzerKühlmaschinenbau GmbH. [online]. Available at: < https://www.bitzer.de/de/ de/?gclid=EAIaIQobChMIpoem eah6wIVVKa WCh2B5QHQEAAYASAAEgIM0_D_BwE>. [Accessed on 9 January 2020].

[19] Cai D, Jiang J, He G, Li K, Niu L and Xiao R (2016). Experimental evaluation on thermal performance of an air-cooled absorption refrigeration cycle with NH3-LiNO3 and NH3-NaSCN refrigerant solutions. Energy Conversion and Management, 120, pp. 32-43.

[20] Cao J, Hong X, Zheng Z, Asim M, Hu M, Wang Q, Pei G and Leung KHM (2020). Performance characteristics of variable conductance loop thermosyphon for energy-efficient building thermal control. Applied Energy, 275, pp. 115337.

[21] Cao T, Lee H, Hwang Y, Radermacher R and Chun $H$ (2015). Performance investigation of engine waste heat powered absorption cycle cooling system for shipboard applications. Applied Thermal Engineering, 90, pp. 820-830.

[22] Carrier Corporation (2019). A World of Comfort - A quick reference guide to sustainable building solutions. [online]. Available at: <http://www. americancoolingandheating.com/wp-content/ uploads/2014/08/Carrier-A-World-Of-Comfort-AQuick-Reference-Guide-to-Sustainable-BuildingSolutions.pdf $>$. [Accessed on 5 March 2020].

[23] Cerezo J, Best R and Romero RJ (2011). A study of a bubble absorber using a plate heat exchanger with $\mathrm{NH}_{3}-\mathrm{H}_{2} \mathrm{O}, \mathrm{NH}_{3}-\mathrm{LiNO}_{3}$ and $\mathrm{NH}_{3}-\mathrm{NaSCN}$. Applied Thermal Engineering, 31(11-12), pp. 1869-1876.

[24] Chan KC, Tso CY, Wu C and Chao CYH (2018). Enhancing the performance of a zeolite $13 \mathrm{X} / \mathrm{CaCl} 2$ - Water adsorption cooling system by improving adsorber design and operation sequence. Energy and Buildings, 158, pp. 1368-1378.

[25] Chua HT, Ng KC, Wang W, Yap C and Wang XL (2004). Transient modeling of a two-bed silica gelwater adsorption chiller. International Journal of Heat and Mass Transfer, 47(4), pp. 659-669.

[26] Chua KJ and Chou SK (2003). Low-cost drying methods for developing countries. Trends in Food Science \& Technology, 14(12), pp. 519-528.

[27] Deng J, Wang RZ and Han GY (2011). A review of thermally activated cooling technologies for combined cooling, heating and power systems. Progress in Energy and Combustion Science, 37(2), pp. 172-203. 
[28] Dong L, Zheng D, Li J, Nie N and Wu X (2013). Suitability prediction and affinity regularity assessment of $\mathrm{H}_{2} \mathrm{O}+$ imidazolium ionic liquid working pairs of absorption cycle by excess property criteria and UNIFAC model. Fluid Phase Equilibria, 348, pp. 1-8.

[29] Du T, Geng H, Zhang Y, Lin H, Li Y, and Yu L (2019). Exact analytical method for active magnetic bearings with rotor eccentricity. IEEE Transactions on Magnetics, 55(12), pp. 1-12.

[30] Fadar AE (2015). Thermal behavior and performance assessment of a solar adsorption cooling system with finned adsorber. Energy, 83, pp. 674-684.

[31] Fan Y, Luo L and Souyri B (2007). Review of solar sorption refrigeration technologies: Development and applications. Renewable and Sustainable Energy Reviews, 11(8), pp. 1758-1775.

[32] Fernández-García A, Zarza E, Valenzuela L and Pérez M (2010). Parabolic-trough solar collectors and their applications. Renewable and Sustainable Energy Reviews, 17(4), pp. 1695-1721.

[33] GEA North America (2020). GEA Chillers (North America) - Brochure (2020). [online]. Available at: < https:/www.gea.com/en/binaries/GEA $\% 20$ Chillers\%20-\%20GEA\%20North\%20America\%20 -\%20brochure\%20-\%20rev\%202-2020_tcm1152263.pdf $>$. [Accessed on 10 January 2020].

[34] Gebreslassie BH, Medrano M and Boer D (2010). Exergy analysis of multi-effect water-LiBr absorption systems: From half to triple effect. Renewable Energy, 35(8), pp. 1773-1782.

[35] Ghafoor A and Munir A (2015). Worldwide overview of solar thermal cooling technologies. Renewable and Sustainable Energy Reviews, 43, pp. 763-774.

[36] Gong LX, Wang RZ, Xia ZZ and Chen CJ (2011). Design and performance prediction of a new generation adsorption chiller using composite adsorbent. Energy Conversion and Management, 52(6), pp. 2345-2350.

[37] Guan X, Zhou J, Jin C, Xu, Y, and Cui H (2019). Influence of different operating conditions on centrifugal compressor surge control with active magnetic bearings. Engineering Applications of Computational Fluid Mechanics, 13(1), pp. 824832.

[38] Habib K, Choudhury B, Chatterjee PK and Saha BB (2013). Study on a solar heat driven dual-mode adsorption chiller. Energy, 63, pp. 133-141.

[39] Hassan HZ, Mohamad AA and Bennacer R (2011). Simulation of an adsorption solar cooling system. Energy, 36(1), pp. 530-537.

[40] Herold K, Radermacher R, Reinhard K, Sanford A (2016). Absorption chillers and heat pumps. Chemical Rubber Company Press, pp. 235-254.
[41] HKSAR Government (2015). Report on application of high efficiency chillers. [online report]. Available at: <https://www.emsd.gov.hk/filemanager/en/ content_764/Aplctn-Hgh-Efcny-Chlrs.pdf $>$. [Accessed on 15 March 2020].

[42] HKSAR Government (2018). Hong Kong energy end-use data 2018, pp. 63-68. [online]. Available at: <https://www.emsd.gov.hk/filemanager/en/ content 762/HKEEUD2018.pdf $>$. [Accessed on 15 March 2020].

[43] Horuz I (1998). A comparison between ammoniawater and water-lithium bromide solutions in vapor absorption refrigeration systems. International Communications in Heat and Mass Transfer, 25(5), pp. 711-721.

[44] Izquierdo M, Venegas M, Rodríguez P and Lecuona A (2004). Crystallization as a limit to develop solar air-cooled $\mathrm{LiBr}-\mathrm{H}_{2} \mathrm{O}$ absorption systems using lowgrade heat. Solar Energy Materials and Solar Cells, 81(2), pp. 205-216.

[45] Jian S, Lin F and Shigang Z (2010). Performance calculation of single effect absorption heat pump using $\mathrm{LiBr}+\mathrm{LiNO}_{3}+\mathrm{H}_{2} \mathrm{O}$ as working fluid. Applied Thermal Engineering, 30(17-18), pp. 26802684.

[46] Jinji S, Yuan R and Jiancheng F (2011). Passive axial magnetic bearing with Halbach magnetized array in magnetically suspended control moment gyro application. Journal of Magnetism and Magnetic Materials, 323(15), pp. 2103-2107.

[47] Johnson Controls (2018). York Commercial \& Industrial HVAC 2018. [online]. Available at: $<$ https://www.johnsoncontrols.com/-/media/jci/ global-capabilities/be/files/be_york_industrial_ commercial_hvac_2018.pdf $>$. [Accessed on $1 \overline{5}$ November 2019].

[48] Kang YT, Akisawa A and Kashiwagi T (1999). An advanced GAX cycle for waste heat recovery: WGAX cycle. Applied Thermal Engineering, 19(9), pp. 933-947.

[49] Karamangil MI, Coskun S, Kaynakli O and Yamankaradeniz N (2010). A simulation study of performance evaluation of single-stage absorption refrigeration system using conventional working fluids and alternatives. Renewable and Sustainable Energy Reviews, 14(7), pp. 1969-1978.

[50] Keçeciler A, Acar Hİ and Doğan A (2000). Thermodynamic analysis of the absorption refrigeration system with geothermal energy: an experimental study. Energy Conversion and Management, 41(1), pp. 37-48.

[51] Kedzierski MA (2001). The effect of lubricant concentration, miscibility, and viscosity on R134a pool boiling. International Journal of Refrigeration, 24(4), pp. 348-366. 
[52] Kim DS and Infante Ferreira CA (2008). Solar refrigeration options - a state-of-the-art review. International Journal of Refrigeration, 31(1), pp. 3-15.

[53] Kim J, Park Y and Lee H (1999). Performance evaluation of absorption chiller using $\mathrm{LiBr}+$ $\mathrm{H}_{2} \mathrm{~N}\left(\mathrm{CH}_{2}\right)_{2} \mathrm{OH}+\mathrm{H}_{2} \mathrm{O}, \mathrm{LiBr}+\mathrm{HO}\left(\mathrm{CH}_{2}\right)_{3} \mathrm{OH}+\mathrm{H}_{2} \mathrm{O}$, and $\mathrm{LiBr}+\left(\mathrm{HOCH}_{2} \mathrm{CH}_{2}\right)_{2} \mathrm{NH}+\mathrm{H}_{2} \mathrm{O}$ as working fluids. Applied Thermal Engineering, 19(2), pp. 217-225.

[54] Koronaki IP, Papoutsis EG and Papaefthimiou VD (2016). Thermodynamic modeling and exergy analysis of a solar adsorption cooling system with cooling tower in Mediterranean conditions. Applied Thermal Engineering, 99, pp. 1027-1038.

[55] Leung M, Lai G, Chan WH, Qin JY and Lee SY (2002). Sponge-ball automatic tube cleaning device for saving energy in a chiller. International Energy Journal, 3, pp. 35-44.

[56] Li R, Dai Y and Cui G (2019). Multi-objective optimization of solar powered adsorption chiller combined with river water heat pump system for air conditioning and space heating application. Energy, 189, pp. 116141.

[57] Manzela AA, Hanriot SM, Cabezas-Gómez L and Sodré JR (2010). Using engine exhaust gas as energy source for an absorption refrigeration system. Applied Energy, 87(4), pp. 1141-1148.

[58] Muthu V, Saravanan R and Renganarayanan S (2008). Experimental studies on R134a-DMAC hot water based vapour absorption refrigeration systems. International Journal of Thermal Sciences, 47(2), pp. 175-181.

[59] Nasruddin N, Lemington L and Alhamid M (2015). Numerical Simulation of a Two-bed Solardriven Adsorption Chiller in a Tropical Climate. International Journal of Technology, 6(4), pp. 594603

[60] N'tsoukpoe KE, Liu H, Le Pierrès N and Luo L (2009). A review on long-term sorption solar energy storage. Renewable and Sustainable Energy Reviews, 13(9), pp. 2385-2396.

[61] Ohji T, Katsuda Y, Amei K and Sakui M (2011). Structure of one-axis controlled repulsive type magnetic bearing system with surface permanent magnets installed and its levitation and rotation Tests. IEEE Transactions on Magnetics, 47(12), pp. 4734-4739.

[62] Oluleye MA and Boukhanouf R (2019). Development trend of solar-powered adsorption refrigeration systems: A review of technologies, cycles, applications, challenges and future research directions. Development, 6(8).

[63] Paris: International Energy Agency (2018). The Future of Cooling. [online]. Available at: $<$ https:// www.iea.org/reports/the-future-of-cooling $>$. [Accessed on 19 June 2019].
[64] Parker SA and Blanchard J (2012). Variable-speed Oil-free Centrifugal Chiller with Magnetic Bearings Assessment. Pacific Northwest Laboratory, pp.138.

[65] Pecharsky VK and Gschneidner KA (2006). Advanced magnetocaloric materials: What does the future hold?. International Journal of Refrigeration, 29(8), pp. 1239-1249.

[66] Qadir N, Said SAM, Mansour RB, Imran H and Khan M (2020). Performance comparison of a twobed solar-driven adsorption chiller with optimal fixed and adaptive cycle times using a silica gel/ water working pair. Renewable Energy, 149, pp. 1000-1017.

[67] Rezk ARM and Al-Dadah RK (2012). Physical and operating conditions effects on silica gel/water adsorption chiller performance. Applied Energy, 49(1), pp. 142-149.

[68] Rouf RA, Alam KCA and Khan MAH (2013). Effect of operating conditions on the performance of adsorption solar cooling run by solar collectors. Procedia Engineering, 56, pp. 607-612.

[69] Sarbu I and Sebarchievici C (2013). Review of solar refrigeration and cooling systems. Energy and Buildings, 67, pp. 286-297.

[70] Sharafian A, Cague CM and Bahrami M (2015). Impact of fin spacing on temperature distribution in adsorption cooling system for vehicle $\mathrm{A} / \mathrm{C}$ applications. International Journal of Refrigeration, 51, pp. 135-143.

[71] Sharma A, Tyagi VV, Chen CR and Buddhi D (2009). Review on thermal energy storage with phase change materials and applications. Renewable and Sustainable Energy Reviews, 13(2), pp. 318345.

[72] Simbolon LM and Hikmat YP (2020). Comparison of utilization an absorption and vapour compression chiller in sub-tropical country building - A feasibility study. International Journal Applied Technology Research, 1(1), pp. 23-37.

[73] Singhal A, Hans S and Jain V (2019). Performance evaluation of wick cooled condenser in vapor compression refrigeration system. International Journal of Advance Research and Innovation, 7(2), pp. 150-152.

[74] Sun Z, Zhang X, Fan T, Yan X, Zhao J, Zhao L and Shi $Z$ (2019). Nonlinear dynamic characteristics analysis of active magnetic bearing system based on cell mapping method with a case study. Mechanical Systems and Signal Processing, 117, pp. 116-137.

[75] Thimmaiah PC, Sharafian A, Huttema W, Cague CM and Bahrami M (2016). Effects of capillaryassisted tubes with different fin geometries on the performance of a low-operating pressure evaporator for adsorption cooling system applications. Applied Energy, 171, pp. 256-265. 
[76] Tian M, Su Y, Zheng H, Pei G, Li G and Riffat S (2018). A review on the recent research progress in the compound parabolic concentrator (CPC) for solar energy applications. Renewable and Sustainable Energy Reviews, 171, pp. 1272-1296.

[77] Tso CY and Chao CYH (2012). Activated carbon, silica-gel and calcium chloride composite adsorbents for energy efficient solar adsorption cooling and dehumidification systems. International Journal of Refrigeration, 35(6), pp. 1626-1638.

[78] Tso CY, Fu SC and Chao CYH (2014). Modeling a solar-powered double bed novel composite adsorbent (silica activated carbon/CaCl2) - Water adsorption chiller. Building Simulation, 7(2), pp. 185-196.

[79] Ugale VD and Pitale AD (2015). A review on working pair used in adsorption cooling system. International Journal of Refrigeration, 23(01), pp. 1530001.

[80] Voyiatzis E, Palyvos JA and Markatos N (2008). Heat-exchanger design and switching-frequency effects on the performance of a continuous type solar adsorption chiller. Applied Energy, 85(12), pp. 1237-1250.

[81] Wang K, Abdelaziz O, Kisari P and Vineyard EA (2011). State-of-the-art review on crystallization control technologies for water/LiBr absorption heat pumps. International Journal of Refrigeration, 34(1), pp. 1325-1337.

[82] Wang RZ and Li Y (2007). Perspectives for natural working fluids in China. International Journal of Refrigeration, 30(4), pp. 568-581.

[83] Wang RZ and Oliveira RG (2006). Adsorption refrigeration - An efficient way to make good use of waste heat and solar energy. Progress in Energy and Combustion Science, 32(4), pp. 424-458.

[84] Wang XL, Chua HT and Ng KC (2004). Simulation of the Silica Gel-Water Adsorption Chillers. In: International Refrigeration and Air Conditioning Conference. Purdue University: Purdue e-Pubs, pp. 1-8.

[85] Wu W, Wang B, Shi W and Li X (2014a). An overview of ammonia-based absorption chillers and heat pumps. Renewable and Sustainable Energy Reviews, 31, pp. 681-707.

[86] Wu W, Wang B, Shi W and Li X (2014b). Absorption heating technologies: A review and perspective. Applied Energy, 130, pp. 51-71.

[87] Wu W, Wang B, Shi W, Li X and You T (2013). A potential solution for thermal imbalance of ground source heat pump systems in cold regions: Ground source absorption heat pump. Renewable Energy, 59, pp. 39-48.
[88] Wu W, Wang B, Shi W, Li X and You T (2014c). Simulation of a combined heating, cooling and domestic hot water system based on ground source absorption heat pump. Applied Energy, 126, pp. 113-222.

[89] Wu W, Wang B, Wang J, Shi W, Li X and You T (2018). Compression-assisted absorption cycles using ammonia and various ionic liquids for cleaner heating. Journal of Cleaner Production, 195, pp. 890-907.

[90] Wu W, Zhang X, Li X, Shi W and Wang B (2012). Comparisons of different working pairs and cycles on the performance of absorption heat pump for heating and domestic hot water in cold regions. Applied Thermal Engineering, 48, pp. 349-358.

[91] Xia ZZ, Yang GZ and Wang RZ (2008). Experimental investigation of capillary-assisted evaporation on the outside surface of horizontal tubes. International Journal of Heat and Mass Transfer, 51(15-16), pp. 4047-4054.

[92] Xu SZ, Wang LW and Wang RZ (2016). Thermodynamic analysis of single-stage and multistage adsorption refrigeration cycles with activated carbon-ammonia working pair. Energy Conversion and Management, 117, pp. 31-42.

[93] Yokozeki A and Shiflett MB (2007). Vapor-liquid equilibria of ammonia+ionic liquid mixtures. Applied Energy, 84(12), pp. 1258-1273.

[94] Yokozeki A and Shiflett MB (2010). Water solubility in ionic liquids and application to absorption vycles. Industrial \& Engineering Chemistry, 49(19), pp. 9496-9503.

[95] Yoon J, Choi K, Moon C, Kim YJ and Kwon O (2003). A study on the advanced performance of an absorption heater/chiller with a solution preheater using waste gas. Applied Thermal Engineering, 23(6), pp. 757-767.

[96] Yu FW and Chan KT (2008). Optimization of water-cooled chiller system with load-based speed control. Applied Energy, 85(10), pp. 931-950.

[97] Yu FW, Chan KT and Sit RKY (2017). Analysis of centrifugal chillers with oil-free magnetic bearings for enhancing building energy performance. Science and Technology for the Built Environment, 23(2), pp. 334-344.

[98] Yu FW, Chan KT, Sit RKY and Yang J (2015). Performance evaluation of oil-free chillers for building energy performance improvement. Procedia Engineering, 121, pp. 975-983.

[99] Zhai XQ, Qu M, Li Y and Wang RZ (2011). A review for research and new design options of solar absorption cooling systems. Renewable and Sustainable Energy Reviews, 15(9), pp. 4416-4423.

[100] Zhang H, Baeyens J, Cáceres G, Degrève J and Lv Y (2016). Thermal energy storage: Recent developments and practical aspects. Progress in Energy and Combustion Science, 53, pp. 1-40. 
[101] Zhu LQ, Tso CY, Chan KC, Wu CL, Chao C, Chen J, He W and Luo SW (2018a). Experimental investigation on composite adsorbent-water pair for a solar-powered adsorption cooling system. Applied Thermal Engineering, 131, pp. 649-659.

[102] Zhu LQ, Tso CY, Chan KC, Wu CL, Chen J and $\mathrm{He}$ W (2018b). Performance investigation of nanostructured composite surfaces for use in adsorption cooling systems with a mass recovery cycle. Science and Technology for the Built Environment, 24(10), pp. 1084-1103.

[103] Zhu LQ, Tso CY, He W, Wu CL and Chao CYH (2017). A field investigation of a solar-powered adsorption cooling system under Guangzhou's climate with various numbers of heat exchangers in the adsorbers. Science and Technology for the Built Environment, pp. 1282-1292. 